\title{
Is There a Place for Resection of HCC in the Presence of Liver Transplantation and Interventional Radiology in Cirrhotic Liver?
}

\author{
Mohamed Abdel Wahab ${ }^{1}$, Khaled Abdel Wahab ${ }^{2}$, Ahmed Shehta ${ }^{1}$, Hosam Hamed ${ }^{1}$
}

${ }^{1}$ Gastroenterology Surgical Center, Mansoura University, Egypt

${ }^{2}$ Mansoura Oncology Center, Mansoura University, Egypt

\section{ABSTRACT}

Hepatocellular carcinoma is the fifth most common cancer worldwide and one of the leading causes of cancer-related mortality. The majority of patients with hepatocellular carcinoma have underlying liver cirrhosis as a result of hepatitis B or hepatitis $\mathrm{C}$ virus, and alcoholic hepatitis. Its management in the presence of liver cirrhosis is a complex condition. Selecting the appropriate treatment modality is dependent not only on tumor stage, but also on the severity of the underlying liver disease. Liver resection and transplantation remain the main course of treatment of HCC. However, liver transplantation is considered nowadays the standard of care for hepatocellular carcinoma because it removes both the tumor and the underlying cirrhotic liver; improving quality of life by restoring a normal liver status. However, the shortage of donors and high costs make liver transplantation less available. Therefore, liver resection remains the commonly used strategy for HCC patients with preserved liver functions. However, liver resection is associated with high peri-operative morbidity and mortality, and high incidence of $\mathrm{HCC}$ recurrence. Here, we review the role of liver resection in the era of liver transplantation and interventional radiology.

Key words: hepatocellular carcinoma, liver resection, liver cirrhosis

\section{INTRODUCTION}

Hepatocellular carcinoma ( $\mathrm{HCC}$ ) is the fifth most common cancer worldwide $(1,2)$ and one of the leading causes of death worldwide, representing a major health problem (3). The vast majority of patients with $\mathrm{HCC}$ have underlying liver cirrhosis (LC) as a result of hepatitis B virus (HBV), hepatitis C virus (HCV) infection, or alcoholic hepatitis (4). In Egypt, HCV is considered as the main predisposing factor for HCC. We previously investigated 1012 patients with HCC, in which HCV was found in nearly $79.6 \%$, while mixed infection with HBV represented about $3.6 \%$ of cases (5). In another study, conducted also in Mansoura University, we observed aflatoxins as a significant contributing factor for HCC patients in the Delta region in Egypt as its level was $32.47 \pm 92.46$ vs. $7.33 \pm 5.5$ for the control group ( $p<0.0001)(6)$. HCC can occur also in individuals without LC. The reported percentage of non-cirrhotic HCC ranges from 7 to 54\%,
Corresponding author: Khaled Mohamed Abdelwahab Lecturer of surgical oncology Mansoura Oncology Center Mansoura University Phone number: 00201001527035 E-mail: khaled14eg@hotmail.com 
depending on demographic area, underlying cause, and the sources of the specimen, such as liver biopsies, autopsies, or resected liver (7)(fig. 1).

It is established that both liver resection and transplantation are the cornerstones for management of HCC. However, LT is superior in its results because it offers a rich resection for cancer, removes the underlying cirrhotic liver; decreasing its future hazards as malignancy and returns the normal liver status. With the change in the criteria for patient selection $(9,10)$, many authors estimated transplantation for even early HCC leads to very good results over liver resection $(9,11,12)$ and similar to cases that underwent liver transplantation for nonmalignant diseases $(9,10,13)$. However, the existing shortage of donors makes this option not applicable for all patients $(14,15)$.

Liver resection is associated with high peri-operative morbidity and mortality, and high incidence of HCC recurrence; especially in cirrhotic liver. However, with the expected worse prognosis in comparison with LT, we raise a question: in cases with liver cirrhosis and developed HCC, does resection still pose a role in the era of liver transplantation and interventional radiology methods?

In cases with $\mathrm{HCC}$ within Milan criteria in cirrhotic liver in the waiting list of LT, LR can be offered as a bridge for liver transplantation. For large HCC (more than $10 \mathrm{~cm}$ ), LR remains the only curative treatment. Caudate lobe resection for HCC in cirrhotic liver is safe and feasible in experienced hands. For HCC cases with obstructive jaundice due to invasion of the extra-hepatic biliary system, resection may be the only curative treatment or as a bridge for liver transplantation.

\section{DISSCUSION}

Liver resection in the context of cirrhosis is associated with high incidence of operative difficulties, postoperative complications, and recurrence rates (14). Recent mortality rate following hepatectomy has been reduced significantly due to preoperative examinations, development of surgical techniques, and improved management of patients, resulting in an increased long-term survival rate (15). However, the 5-year recurrence rate of $\mathrm{HCC}$ after hepatectomy remains high at $77 \%$ to $100 \%$ (16).

Prognosis following LR in those patients with early HCC concomitant with LC may vary. The findings of Yeh et al. showed that HCC patients with LC who had an operation of hepatic resection should be stratified based on the tumor size, the high value of alkaline phosphatase, satellite lesions, and vascular invasion (17). Similarly, several factors have been documented to be responsible for possible reduced

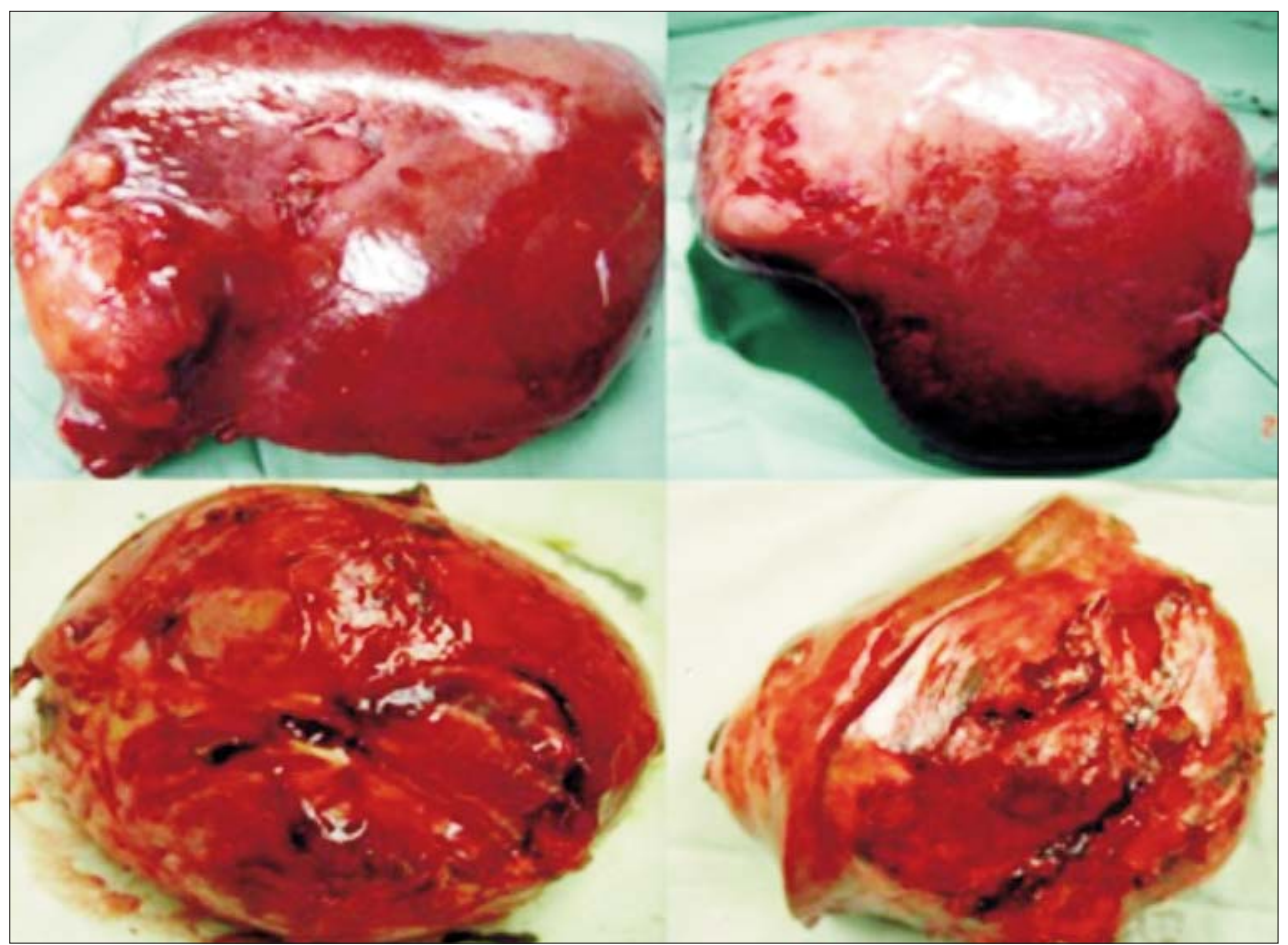

Figure 1 - Large HCC in normal liver 
survival after hepatic resection for early $\operatorname{HCC}(18,19)$. In our study, done on 175 patients with HCC on top of cirrhotic liver, we concluded that LR in cirrhotic liver with preserved liver function can be performed safely, but is associated with high post-resection recurrence rates (20).

The restriction of surgical resection can be disputed for several reasons. First, the safety of liver surgery has markedly improved over the last years, making liver resection a technically feasible option even for patients with cirrhosis or large tumor lesions $(15,21)$. Second, LT is a non-projectable therapy option comprising the risk of cancer progress while waiting for a suitable organ $(22,23)$. Finally, the sensitivity and specificity of current diagnostic means are both limited (24), leading to erroneous classifications with serious consequences on therapeutic goals.

\section{Resection as a bridge to liver transplantation for HCC in cirrhosis}

The superiority of transplantation over LR has been proved through recurrence and survival numbers $(9,11)$. However, the problems regarding short donors and long waiting lists made it an inapplicable choice for all patients $(25,26)$. Therefore, resection is feasible for those patients planning for a transplant in case recurrence occurred $(14,15,28)$.

This plan relies on theories that assume that a percent of these cases may live free of tumor after resection for years, and that transplantation as a second option in a bit more hazardous than if it was performed as a first option (29).

Bleeding was estimated to increase in secondary transplanted cases when compared with primary ones. Survival was also assumed to be affected greatly after secondary LT ( $39 \%$ versus $61 \%$ at 5 years). However, these hazards could be decreased using either transthoracic or laparoscopic approaches that usually results in less adhesions or by using other lines of treatments, such as percutaneous radiofrequency (29).

In practice, this 2-stage strategy should not be considered as routine practice: it should be reserved only for selected patients with low risk of recurrence after resection. On the other hand, cases that have factors affecting disease-free survival after resection should be excluded such as those with multi-nodular tumors (30) Child-Pugh score B or C $(31,32)$, serum alpha-fetoprotein levels more than $32 \mathrm{ng} / \mathrm{ml}$ (23) or serum aminotransferase greater than twice the normal levels $(33,34)$ hepatitis C-related HCC $(35,36)$ microscopic vascular invasion $(30,37)$. Primary transplan- tation would be a more appropriate option for this subset of patients. Sometimes, we can apply this 2-strategy technique in patients planned for transplantation during the waiting time of LT to avoid tumor progression (38-40).

\section{Large tumors}

With the evolving number of HCV patients, we will not be able to perform screening to all cases; especially in developing countries due to increased costs of this procedure, leading to more patients that may be first discovered with a larger tumor burden (41).

Management tools for such huge tumors are limited. Such tumors pose higher probability for recurrence $(42,43)$, may contain undetected small vessels invasion (44) and tend to have an aggressive course that may be due to unknown genetic factors (45). According to the experience of Mazzaferro et al., liver transplantation for such cases poses a bad outcome regarding liver function and incidence of recurrence (10). Also, application of interventional radiology methods for those cases were not preferred, as it showed the same worse prognosis (46). Chemoembolization was one of the methods that was tried for such category of tumors with shown poor short-term outcomes and unknown long-term results (47). Among all these options, resection appeared to the best option in large tumors, with proven safety in high volume centers and acceptable morbidity (48-51) (Fig. 2, 3). Shah and his team performed a study to evaluate results of resection in large tumors and comparing them to cases posing smaller tumors $(<10 \mathrm{~cm})$ and to detect the factors affecting the proposed incidence of recurrence (41). Their results showed that overall survival was not significantly different ( $54 \%$ vs. $53 \%$ at 5 years). In comparison, other articles reported lower overall survival rates for resection of such large tumors $(48,49,52)$.

With accurate preoperative risk assessment, and advanced surgical techniques using recent technology for coagulation and vessel sealing, resection of such tumors can done safely and with the least expected complications (53).

\section{Caudate lobe HCC}

The caudate lobe could be a primary site for HCC and also a site of metastatic malignancy (54). Caudate resection can be performed as an extension of a lobectomy or other types of hepatectomy or as isolated resection, which is the most demanding 
Figure 2 - CT scan showing large exophytic hepatocellular carcinoma in cirrhotic liver. (a) - Large HCC right hemi-liver, (b) - Large exophytic HCC in left lateral section.

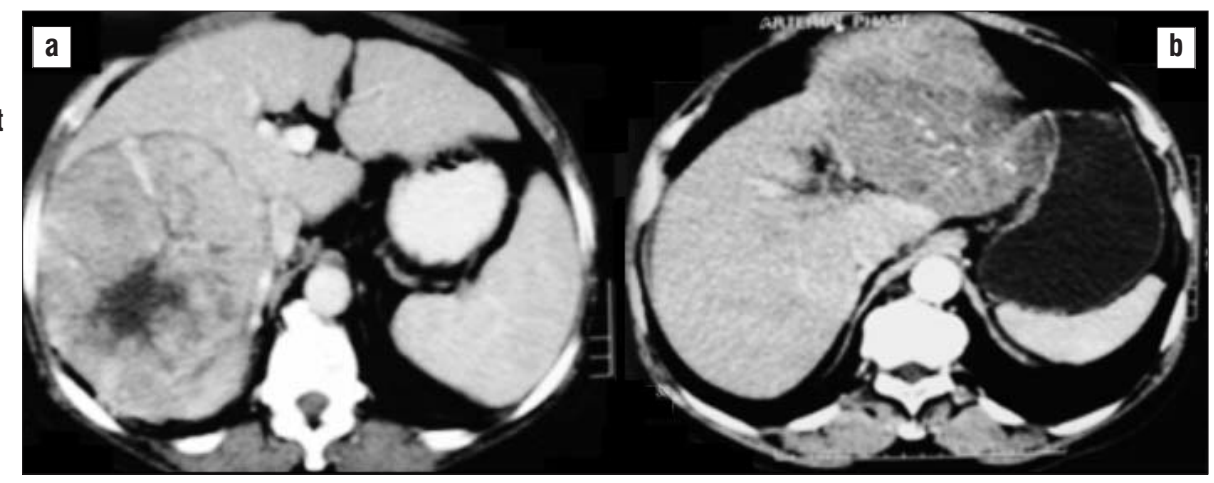

Figure 3 - Operative photos of large exophytic hepatocellular carcinoma. (a) - Exophytic bleeding HCC from left lateral section, (b) - Large exophytic HCC from segment VI, (c) - Exophytic HCC from segment VIII (d) - Large exophytic HCC from left lateral section.

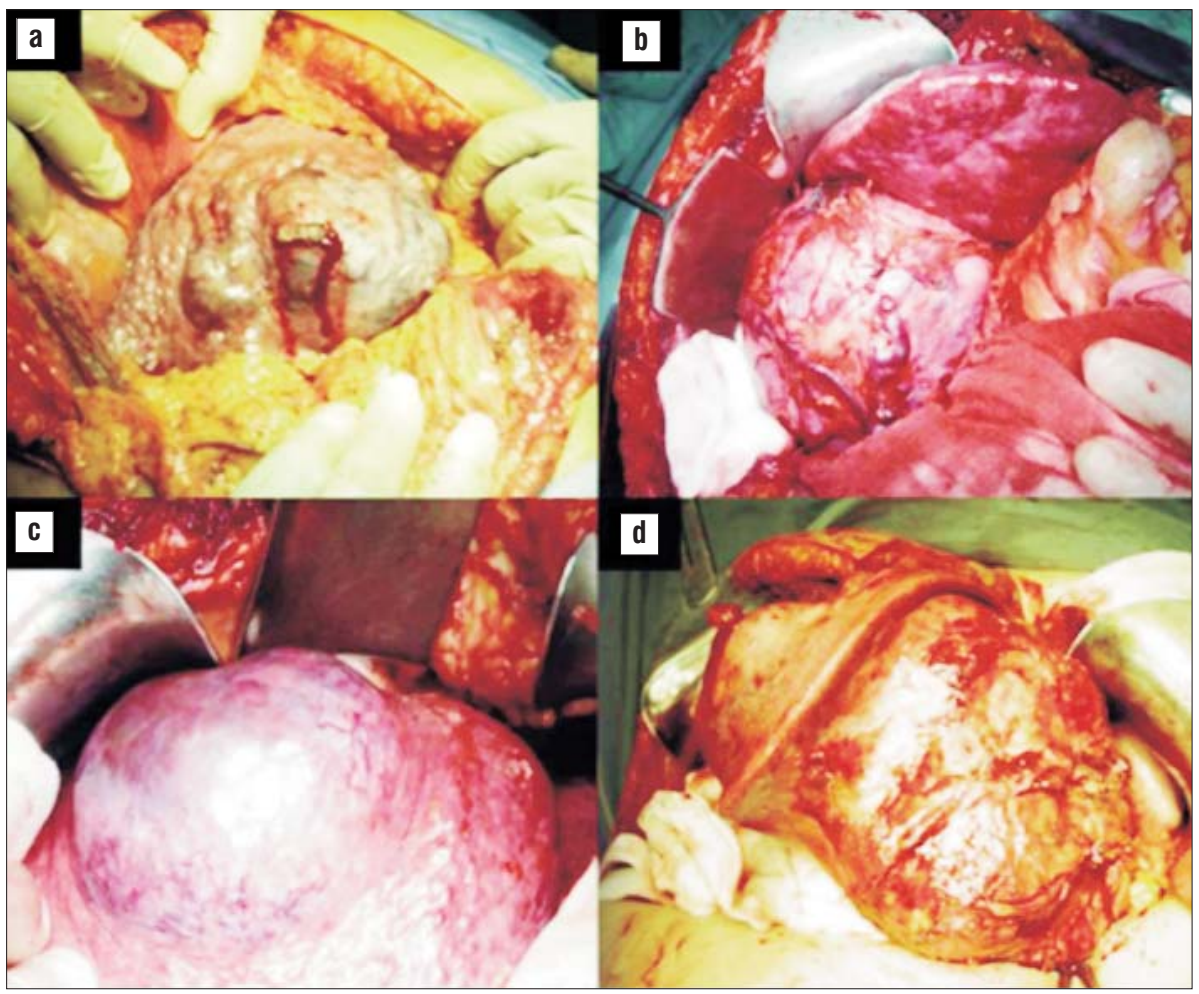

from a technical standpoint (55). Therefore, surgery for HCC originating in the caudate lobe is challenging for hepatic surgeons $(56,57)$. Non-surgical treatment such as percutaneous ethanol injection, RFA and TACE have been developed, but have been thought to be technically difficult. Also, the results are less certain than with surgery (58-60). Liver resection for caudate lobe tumors can now be performed in high-volume centers with an acceptable morbidity of $50 \%-60 \%$ and no mortality $(61,62)$. In our series the rate of post-operative complications was 33\% with no mortality which was comparable to other series (table 1) (63).

Thus, caudate lobe resection appears to be well-tolerated, even in patients with poor liver function. Ikegami et al. reported that limited resection of HCC in the caudate lobe confers prognostic values similar to those obtained in other segments (59). Furthermore, other authors have reported comparable survival rates for patients with HCC in the caudate lobe and those with HCC in other locations $(58,59)$. The previous reports were comparable to our series in which the overall survival rates after isolated caudate lobectomy were $62 \%$ and $34 \%$ at 1 and 3 years, respectively; for those after hepatectomy for HCC in other locations, the rates were $68.6 \%$ and $29.6 \%$, respectively (20). We could conclude from our study that isolated caudate lobe resection is a feasible procedure and can be undertaken with low morbidity and nil mortality. It also maximally spares hepatic parenchyma in patients with hepatic dysfunction. Careful technique and detailed anatomic knowledge of the caudate lobe are essential for the safe use of this procedure (63)(fig. 4, 5, 6). 
Table 1- Results of different studies for caudate lobe resection.

\begin{tabular}{lcccccc}
\hline Study & Year & $\begin{array}{c}\text { Number } \\
\text { of patients }\end{array}$ & $\begin{array}{c}\text { Morbidity } \\
\mathbf{( \% )}\end{array}$ & $\begin{array}{c}\text { Mortality } \\
\mathbf{( \% )}\end{array}$ & $\begin{array}{c}\text { Recurrence } \\
\mathbf{( \% )}\end{array}$ & Survival \\
\hline Yamamoto (14) & 2004 & 15 & 13 & 0 & 66 & $70 \%$ at 3 years \\
\hline Tanaka (10) & 2005 & 20 & 60 & 0 & 50 & $25 \%$ at 5 years \\
\hline Wen (16) & 2008 & 11 & 45 & 0 & 54 & $48 \%$ at 16 months \\
\hline Sakoda (17) & 2009 & 12 & 16 & 0.08 & 41 & $50 \%$ at 3 years \\
\hline Liu Peng (18) & 2010 & 114 & 18 & 0 & 66 & $31 \%$ at 5 years \\
\hline Wahab (62) & 2011 & 30 & 33 & 0 & 40 & $11 \%$ at 5 years \\
\hline
\end{tabular}

Figure 4 - CT scan of large caudate lobe HCC, (a) - Preoperative, (b)- After isolated caudate lobe resection.

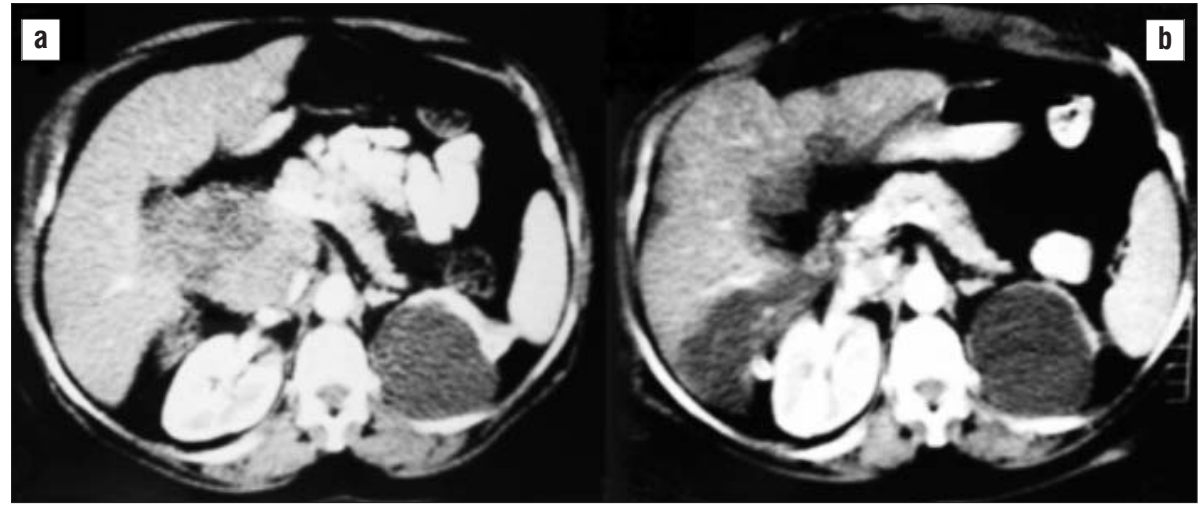

\section{HCC invading the biliary tree}

Jaundice is present in $19 \%$ to $40 \%$ of patients with HCC at the time of diagnosis. However, obstructive jaundice is uncommon as the main clinical feature of HCC (64). Jaundice in patients with primary HCC usually results from diffuse tumour infiltration, hilar invasion, severe cirrhosis, progressive liver failure, or a combination of these factors. The prognosis in these cases is dismal, and death follows in a short time. According to some recent literature, however, a phenomenon has

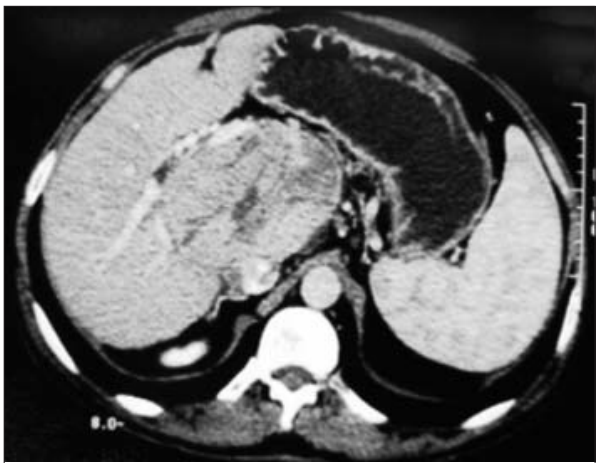

Figure 5 - CT scan of large caudate lobe HCC.
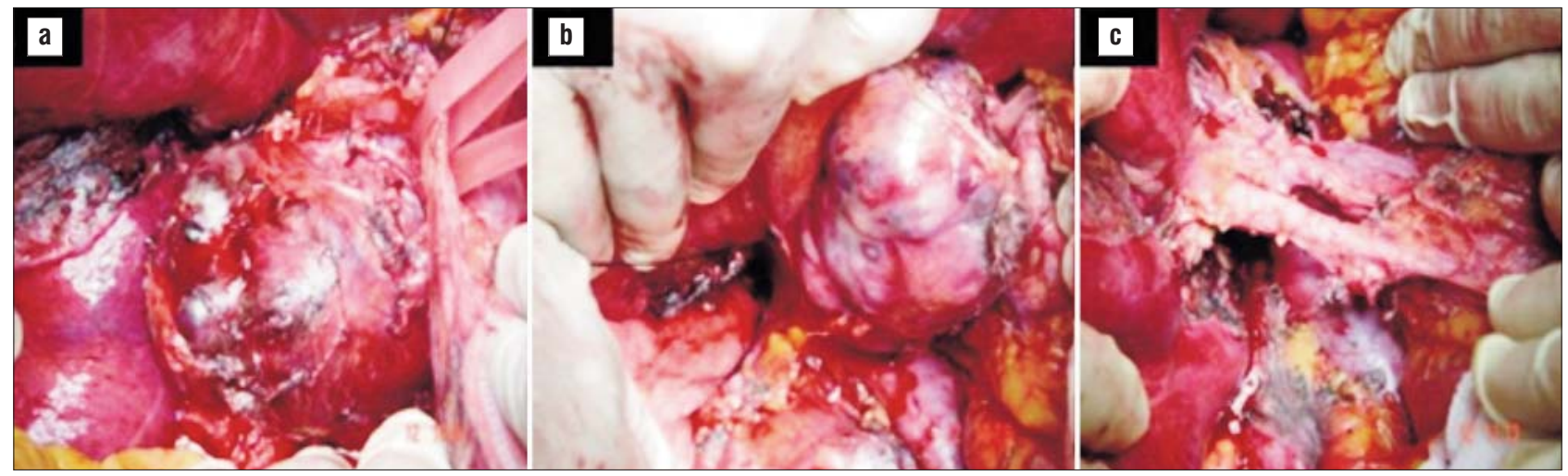

Figure 6 - Operative photos of resection of large caudate lobe HCC. (a) - After dissection of the porta hepatis from the tumor,

(b) - Dissection of the tumor from the IVC, (c) - After removal of the tumor with empty space between porta hepatis and the IVC. 
been found that patients with primary HCC and obstructive jaundice due to biliary tumour thrombus may benefit from surgical intervention, which may result in long-term resolution of symptoms and, occasionally, cure (fig. 7)(65-67).

Significantly, advances in diagnostic means have allowed increasingly accurate preoperative diagnosis of HCC with obstructive jaundice due to biliary tumor thrombi. The bile duct can be obstructed by tumor thrombi, hemobilia, tumor compression, or tumor infiltration. Biliary tumor thrombi have been identified in $2 \%$ to $9 \%$ of autopsy and surgical specimens.

Several reports on HCCs with biliary tumor thrombi have reviewed autopsy cases or patients who underwent palliative treatment $(66,68,69)$. Few studies have investigated resection of HCCs with obstructive jaundice due to biliary tumor thrombi in regard to survival and found that $L R$ is the only line of treatment of those patients $(66,70-72)$.

\section{Local recurrence after liver transplantation}

After liver transplantation, recurrence of HCC is not that less; with reported cases in about $16 \%$ of patients. Such recurrence affects the outcome greatly. Management of such cases have attracted the attention of all experts in the field: this can be clearly shown by the increased number of studies during the past years (73).

In spite of this increased number of publications, there are no RCT or even large cohorts addressing this issue.

According to many articles (73-78), time elapsed since LT and the appearance of recurrence is an important prognostic factor regarding survival, with worst prognosis expected with early HCC recurrence (within 24 months). Early HCC recurrence could be due to non-detectable extra-hepatic spread that was found before performing liver transplantation, and also as a consequence of circulating HCC cell clones engrafting and growing in a target organ in the post-transplant period (79).

On the other hand, late recurrence was explained to be due to late engrafting of HCC cells that remained latent and less numerous for a longer time after liver transplantation $(75,79)$. In LT patients, immunosuppression is expected to have a major effect on the percent recurrence of $\mathrm{HCC}(80,81)$.

For both isolated hepatic and extra-hepatic metastases, surgical resection was found as the best treatment option offering longer survival chance (82-84).

Post-operative mortality and morbidity were very low in both resection of grafted liver and other organ metastases (e.g., lung, adrenal gland). Based on the

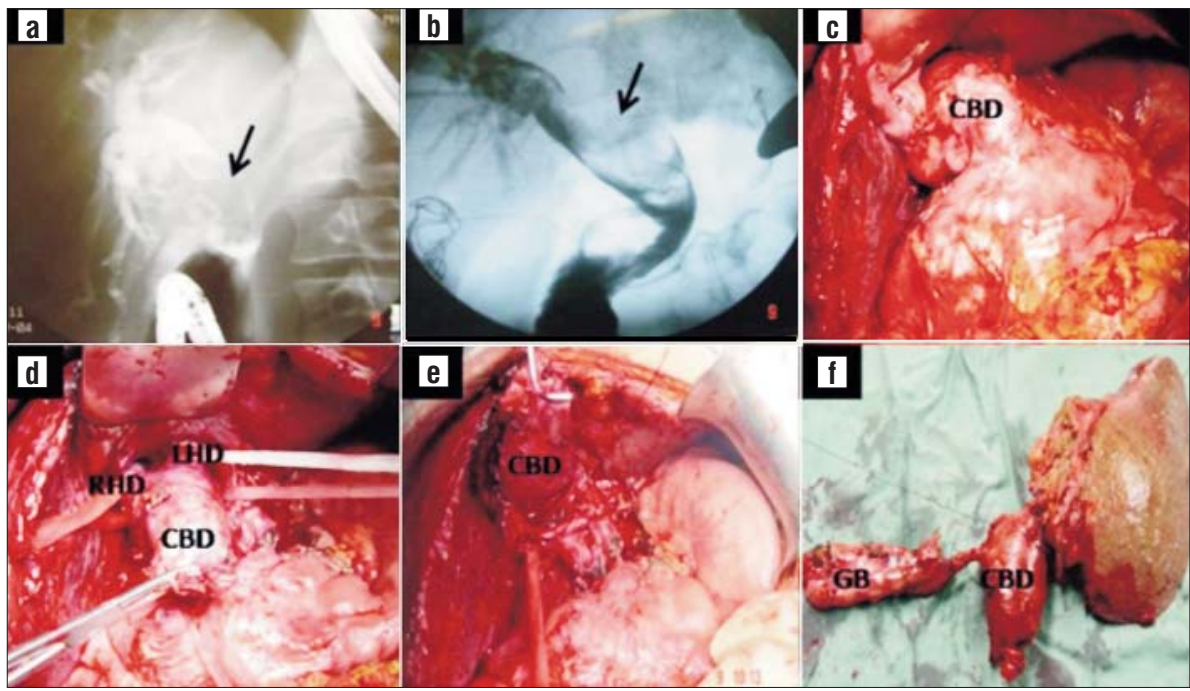

Figure 7 - Left lobe HCC in cirrhotic liver invading the extra-hepatic biliary system. (a) - ERCP photo showing large filling defect (arrow) inside the common bile duct, (b) - IO cholangiogram showing the same findings, (c) - Operative photo of distended common bile duct with tumor thrombus, (d) - After dissection of the distal common bile duct and both right and left hepatic ducts, (e) - After division of the distal common bile duct, (f) - Postoperative photo of resected left hemi-liver and extra-hepatic biliary system (CBD, common bile duct; RHD, right hepatic duct; LHD, left hepatic duct; GB, gall bladder). 
current knowledge, surgery for HCC recurrence is a valuable option if performed in selected patients with curative intents, and we can offer it whenever possible. On the contrary, little is known about re-transplantation for intra-hepatic recurrent HCC, and it is currently considered not appropriate (85).

Unresectable but still limited HCC recurrence may undergo loco-regional therapy including TACE, SIRT, and RFA, with accepted survival rates (6). These treatments appeared to be safe and well-tolerated and may be repeated multiple times or combined in a multimodality approach (86-88).

\section{CONCLUSION}

Liver resection should be considered when technically and functionally feasible, or after failure of non-surgical as palliative approach. In our hands, individual patient selection by an expert panel of experienced liver specialists appears to be more reliable than existing classification systems for the prediction of safe resection in HCC patients.

In the era of LT and interventional radiology as methods for HCC management in LC, LR still has a role. LR can be offered as a bridge for liver transplantation. In large tumors more than $10 \mathrm{~cm}$, the only curative line of treatment is resection. Caudate lobe resection for $\mathrm{HCC}$ in cirrhotic liver is safe and feasible in experienced hands. For HCC cases with obstructive jaundice due to invasion of the extra-hepatic biliary system, resection may be the only curative treatment or as a bridge for liver transplantation.

\section{REFERENCES}

1. Li T, Fan J, Qin L-X, Zhou J, Sun H-C, Qiu S-J, et al. Risk factors, prognosis, and management of early and late intrahepatic recurrence after resection of primary clear cell carcinoma of the liver. Ann Surg Oncol. United States; 2011 Jul;18(7):1955-63.

2. Llovet JM, Ricci S, Mazzaferro V, Hilgard P, Gane E, Blanc J-F, et al. Sorafenib in advanced hepatocellular carcinoma. N Engl J Med. United States; 2008 Jul;359(4):378-90.

3. Waghray A, Murali AR, Menon KN. Hepatocellular carcinoma: From diagnosis to treatment. World J Hepatol. United States; 2015 May;7(8):1020-9.

4. Wang F-S, Fan J-G, Zhang Z, Gao B, Wang H-Y. The global burden of liver disease: the major impact of China. Hepatology. United States; 2014 Dec;60(6):2099-108.

5. Abdel-Wahab M, El-Ghawalby N, Mostafa M, Sultan A, El-Sadany M, Fathy 0 , et al. Epidemiology of hepatocellular carcinoma in lower Egypt, Mansoura Gastroenterology Center. Hepatogastroenterology. Greece; 2007;54(73):157-62.

6. Abdel-Wahab M, Mostafa M, Sabry M, el-Farrash M, Yousef T. Aflatoxins as a risk factor for hepatocellular carcinoma in Egypt, Mansoura Gastroenterology Center study. Hepatogastroenterology. Greece; 2008;55(86-87):1754-9.

7. Wang Q, Fiel Ml, Blank S, Luan W, Kadri H, Kim KW, et al. Impact of liver fibrosis on prognosis following liver resection for hepatitis
B-associated hepatocellular carcinoma. Br J Cancer. England; 2013 Aug;109(3):573-81.

8. de Lope CR, Tremosini S, Forner A, Reig M, Bruix J. Management of HCC. J Hepatol. England; 2012;56 Suppl 1:S75-87.

9. Bismuth H, Chiche L, Adam R, Castaing D, Diamond T, Dennison A. Liver resection versus transplantation for hepatocellular carcinoma in cirrhotic patients. Ann Surg. UNITED STATES; 1993 Aug;218(2): $145-51$.

10. Mazzaferro V, Regalia E, Doci R, Andreola S, Pulvirenti A, Bozzetti F, et al. Liver transplantation for the treatment of small hepatocellular carcinomas in patients with cirrhosis. N Engl J Med. UNITED STATES; $1996 \mathrm{Mar} ; 334(11): 693-9$.

11. Michel J, Suc B, Montpeyroux F, Hachemanne S, Blanc P, Domergue $\mathrm{J}$, et al. Liver resection or transplantation for hepatocellular carcinoma? Retrospective analysis of 215 patients with cirrhosis. J Hepatol. DENMARK; 1997 Jun;26(6):1274-80.

12. Sarasin FP, Giostra E, Mentha G, Hadengue A. Partial hepatectomy or orthotopic liver transplantation for the treatment of resectable hepatocellular carcinoma? A cost-effectiveness perspective. Hepatology. UNITED STATES; 1998 Aug;28(2):436-42.

13. Hemming AW, Cattral MS, Reed Al, Van Der Werf WJ, Greig PD, Howard RJ. Liver transplantation for hepatocellular carcinoma. Ann Surg. United States; 2001 May;233(5):652-9.

14. Farges 0, Malassagne B, Flejou JF, Balzan S, Sauvanet A, Belghiti J. Risk of major liver resection in patients with underlying chronic liver disease: a reappraisal. Ann Surg. UNITED STATES; 1999 Feb;229(2): 210-5.

15. Poon RT, Fan ST, Lo CM, Ng IO, Liu CL, Lam CM, et al. Improving survival results after resection of hepatocellular carcinoma: a prospective study of 377 patients over 10 years. Ann Surg. United States; 2001 Jul;234(1):63-70.

16. Minagawa M, Makuuchi M, Takayama T, Kokudo N. Selection criteria for repeat hepatectomy in patients with recurrent hepatocellular carcinoma. Ann Surg. United States; 2003 Nov;238(5):703-10.

17. Yeh C-N, Chen M-F, Lee W-C, Jeng L-B. Prognostic factors of hepatic resection for hepatocellular carcinoma with cirrhosis: univariate and multivariate analysis. J Surg Oncol. United States; 2002 Dec;81(4):195-202.

18. Nathan H, Schulick RD, Choti MA, Pawlik TM. Predictors of survival after resection of early hepatocellular carcinoma. Ann Surg. United States; 2009 May;249(5):799-805.

19. Kaibori M, Saito T, Matsui Y, Uchida Y, Ishizaki M, Kamiyama Y. A review of the prognostic factors in patients with recurrence after liver resection for hepatocellular carcinoma. Am J Surg. United States; 2007 Apr;193(4):431-7.

20. Abdel-Wahab M, El-Husseiny TS, El Hanafy E, El Shobary M, Hamdy E. Prognostic factors affecting survival and recurrence after hepatic resection for hepatocellular carcinoma in cirrhotic liver. Langenbecks Arch Surg. Germany; 2010 Aug;395(6):625-32.

21. Schnitzbauer AA, Lang SA, Goessmann H, Nadalin S, Baumgart J, Farkas SA, et al. Right portal vein ligation combined with in situ splitting induces rapid left lateral liver lobe hypertrophy enabling 2staged extended right hepatic resection in small-for-size settings. Ann Surg. United States; 2012 Mar;255(3):405-14.

22. Earl TM, Chapman WC. Hepatocellular Carcinoma: Resection versus Transplantation. Semin Liver Dis. 2013;33(3):282-92.

23. Thomas MB, Zhu AX. Hepatocellular carcinoma: the need for progress. J Clin Oncol. United States; 2005 May;23(13):2892-9.

24. El-Serag HB, Marrero JA, Rudolph L, Reddy KR. Diagnosis and Treatment of Hepatocellular Carcinoma. Gastroenterology [Internet]. Elsevier; 2016 Mar 4;134(6):1752-63. Available from: http://dx.doi.org/10.1053/j.gastro.2008.02.090

25. Befeler AS, Di Bisceglie AM. Hepatocellular carcinoma: diagnosis and treatment. Gastroenterology. United States; 2002 May;122(6): 1609-19.

26. Bismuth H, Majno PE, Adam R. Liver transplantation for hepatocellular carcinoma. Semin Liver Dis. UNITED STATES; 1999;19(3):311-22.

27. Majno PE, Sarasin FP, Mentha G, Hadengue A. Primary liver resection and salvage transplantation or primary liver transplantation in patients with single, small hepatocellular carcinoma and preserved liver function: an outcome-oriented decision analysis. Hepatology. UNITED 
STATES; 2000 Apr;31(4):899-906.

28. Yamamoto J, Iwatsuki S, Kosuge T, Dvorchik I, Shimada K, Marsh JW, et al. Should hepatomas be treated with hepatic resection or transplantation? Cancer. UNITED STATES; 1999 Oct;86(7):1151-8.

29. Adam R, Azoulay D, Castaing D, Eshkenazy R, Pascal G, Hashizume K, et al. Liver resection as a bridge to transplantation for hepatocellular carcinoma on cirrhosis: a reasonable strategy? Ann Surg. United States; 2003 Oct;238(4):508-9.

30. Poon RT-P, Fan ST, Lo CM, Liu CL, Wong J. Long-term survival and pattern of recurrence after resection of small hepatocellular carcinoma in patients with preserved liver function: implications for a strategy of salvage transplantation. Ann Surg. United States; 2002 Mar;235(3) :373-82.

31. Arii S, Yamaoka Y, Futagawa S, Inoue K, Kobayashi K, Kojiro M, et al. Results of surgical and nonsurgical treatment for small-sized hepatocellular carcinomas: a retrospective and nationwide survey in Japan. The Liver Cancer Study Group of Japan. Hepatology. UNITED STATES 2000 Dec;32(6):1224-9.

32. Wayne JD, Lauwers GY, Ikai I, Doherty DA, Belghiti J, Yamaoka Y, et al. Preoperative predictors of survival after resection of small hepatocellular carcinomas. Ann Surg. United States; 2002 May;235(5): 721-2.

33. Tarao K, Takemiya S, Tamai S, Sugimasa Y, Ohkawa S, Akaike M, et al. Relationship between the recurrence of hepatocellular carcinoma (HCC) and serum alanine aminotransferase levels in hepatectomized patients with hepatitis $\mathrm{C}$ virus-associated cirrhosis and HCC. Cancer. UNITED STATES; 1997 Feb;79(4):688-94.

34. Ercolani G, Grazi GL, Ravaioli M, Del Gaudio M, Gardini A, Cescon M, et al. Liver resection for hepatocellular carcinoma on cirrhosis: univariate and multivariate analysis of risk factors for intrahepatic recurrence. Ann Surg. United States; 2003 Apr;237(4):536-43.

35. Takenaka K, Yamamoto K, Taketomi A, Itasaka H, Adachi E, Shirabe K, et al. A comparison of the surgical results in patients with hepatitis $B$ versus hepatitis $\mathrm{C}$-related hepatocellular carcinoma. Hepatology. UNITED STATES; 1995 Jul:22(1):20-4

36. Miyagawa S, Kawasaki S, Makuuchi M. Comparison of the characteristics of hepatocellular carcinoma between hepatitis B and C viral infection: tumor multicentricity in cirrhotic liver with hepatitis C. Hepatology. UNITED STATES; 1996 Aug;24(2):307-10.

37. Imamura $\mathrm{H}$, Matsuyama $\mathrm{Y}$, Tanaka $\mathrm{E}$, Ohkubo $\mathrm{T}$, Hasegawa $\mathrm{K}$ Miyagawa S, et al. Risk factors contributing to early and late phase intrahepatic recurrence of hepatocellular carcinoma after hepatectomy. J Hepatol. England; 2003 Feb;38(2):200-7.

38. Pulvirenti A, Garbagnati F, Regalia E, Coppa J, Marchiano A, Romito R, et al. Experience with radiofrequency ablation of small hepatocellular carcinomas before liver transplantation. Transplant Proc. United States; 2001;33(1-2):1516-7.

39. Curley SA, Izzo F, Ellis LM, Nicolas Vauthey J, Vallone $P$. Radiofrequency ablation of hepatocellular cancer in 110 patients with cirrhosis. Ann Surg. UNITED STATES; 2000 Sep;232(3):381-91.

40. Llovet JM, Mas X, Aponte JJ, Fuster J, Navasa M, Christensen E, et al. Cost effectiveness of adjuvant therapy for hepatocellular carcinoma during the waiting list for liver transplantation. Gut. England; 2002 Jan;50(1):123-8.

41. Shah SA, Wei AC, Cleary SP, Yang I, McGilvray ID, Gallinger S, et al Prognosis and results after resection of very large $(>0 \mathrm{r}=10 \mathrm{~cm})$ hepatocellular carcinoma. J Gastrointest Surg. United States; 2007 May;11(5):589-95.

42. Shah SA, Greig PD, Gallinger S, Cattral MS, Dixon E, Kim RD, et al. Factors associated with early recurrence after resection for hepatocellular carcinoma and outcomes. J Am Coll Surg. United States; 2006 Feb;202(2):275-83.

43. Regimbeau JM, Abdalla EK, Vauthey JN, Lauwers GY, Durand F, Nagorney DM, et al. Risk factors for early death due to recurrence after liver resection for hepatocellular carcinoma: results of a multicenter study. J Surg Oncol. United States; 2004 Jan;85(1):36-41.

44. Pawlik TM, Delman KA, Vauthey J-N, Nagorney DM, Ng IO-L, Ikai I, et al. Tumor size predicts vascular invasion and histologic grade: Implications for selection of surgical treatment for hepatocellular carcinoma. Liver Transplant Off Publ Am Assoc Study Liver Dis Int Liver Transplant Soc. United States; 2005 Sep;11(9):1086-92.
45. Llovet JM, Schwartz M, Mazzaferro V. Resection and liver transplantation for hepatocellular carcinoma. Semin Liver Dis. United States; 2005;25(2):181-200.

46. Livraghi T, Giorgio A, Marin G, Salmi A, de Sio I, Bolondi L, et al. Hepatocellular carcinoma and cirrhosis in 746 patients: long-term results of percutaneous ethanol injection. Radiology. UNITED STATES; 1995 0ct;197(1):101-8.

47. Harada T, Matsuo K, Inoue T, Tamesue S, Inoue T, Nakamura H. Is preoperative hepatic arterial chemoembolization safe and effective for hepatocellular carcinoma? Ann Surg. UNITED STATES; 1996 Jul;224(1):4-9.

48. Pawlik TM, Poon RT, Abdalla EK, Zorzi D, Ikai I, Curley SA, et al. Critical appraisal of the clinical and pathologic predictors of survival after resection of large hepatocellular carcinoma. Arch Surg. United States; 2005 May;140(5):450-8.

49. Liau K-H, Ruo L, Shia J, Padela A, Gonen M, Jarnagin WR, et al. Outcome of partial hepatectomy for large $(>10 \mathrm{~cm})$ hepatocellular carcinoma. Cancer. United States; 2005 Nov;104(9):1948-55.

50. Poon RTP, Fan ST, Lo CM, Liu CL, Lam CM, Yuen WK, et al. Extended hepatic resection for hepatocellular carcinoma in patients with cirrhosis: is it justified? Ann Surg. United States; 2002 Nov;236(5):602-11.

51. Fong $\mathrm{Y}$, Sun RL, Jarnagin W, Blumgart LH. An analysis of 412 cases of hepatocellular carcinoma at a Western center. Ann Surg. UNITED STATES; 1999 Jun;229(6):790-800.

52. Roayaie S, Schwartz JD, Sung MW, Emre SH, Miller CM, Gondolesi $\mathrm{GE}$, et al. Recurrence of hepatocellular carcinoma after liver transplant: patterns and prognosis. Liver Transplant Off Publ Am Assoc Study Liver Dis Int Liver Transplant Soc. United States; 2004 Apr;10(4):534-40.

53. Poon RT, Fan ST, Lo CM, Liu CL, Lam CM, Yuen WK, et al. Improving perioperative outcome expands the role of hepatectomy in management of benign and malignant hepatobiliary diseases: analysis of 1222 consecutive patients from a prospective database. Ann Surg. United States; 2004 0ct;240(4):610-98.

54. Tono T, Ohzato H, Fukunaga M, Hasuike $\mathrm{Y}$, Nakagawa $\mathrm{H}$, Monden T, et al. Surgical treatment of hepatic caudate lobe metastases originating from colorectal primaries. Int Surg. Italy; 2000;85(3):237-42.

55. Elias D, Lasser PH, Desruennes E, Mankarios H, Jiang Y. Surgical approach to segment I for malignant tumors of the liver. Surg Gynecol Obstet. UNITED STATES; 1992 Jul;175(1):17-24.

56. Takayama T, Makuuchi M. Segmental liver resections, present and future-caudate lobe resection for liver tumors. Hepatogastroenterology. GREECE; 1998;45(19):20-3.

57. Yamamoto J, Kosuge T, Shimada K, Yamasaki S, Takayama T, Makuuchi M. Anterior transhepatic approach for isolated resection of the caudate lobe of the liver. World J Surg. UNITED STATES; 1999 Jan;23(1):97-101

58. Sarmiento JM, Que FG, Nagorney DM. Surgical outcomes of isolated caudate lobe resection: a single series of 19 patients. Surgery. United States; 2002 Oct:132(4):697-9.

59. Ikegami T, Ezaki T, Ishida T, Aimitsu S, Fujihara M, Mori M. Limited hepatic resection for hepatocellular carcinoma in the caudate lobe. World J Surg. United States; 2004 Jul;28(7):697-701.

60. Lu CL, Wu JC, Chiang JH, Lui WY, Chau GY, Lee SD. Hepatocellular carcinoma in the caudate lobe: early diagnosis and active treatment may result in long-term survival. J Gastroenterol Hepatol. AUSTRALIA; $1997 \mathrm{Feb}: 12(2): 144-8$.

61. Hawkins WG, DeMatteo RP, Cohen MS, Jarnagin WR, Fong $Y$, D'Angelica $M$, et al. Caudate hepatectomy for cancer: a single institution experience with 150 patients. J Am Coll Surg. United States; 2005 Mar:200(3):345-52.

62. Tanaka S, Shimada M, Shirabe K, Maehara S-I, Tsujita E, Taketomi A, et al. Surgical outcome of patients with hepatocellular carcinoma originating in the caudate lobe. Am J Surg. United States; 2005 Sep;190(3):451-5.

63. Wahab MA, Fathy O, Elhanafy E, Atif E, Sultan AM, Salah T, et al. Caudate lobe resection for hepatocellular carcinoma. Hepatogastroenterology. Greece; 2011;58(112):1904-8.

64. Chen M-F. Icteric type hepatocellular carcinoma: clinical features, diagnosis and treatment. Chang Gung Med J. China (Republic 1949- ); 2002 Aug;25(8):496-501. 
65. Tantawi B, Cherqui D, Tran van Nhieu J, Kracht M, Fagniez PL. Surgery for biliary obstruction by tumour thrombus in primary liver cancer. $\mathrm{Br}$ J Surg. ENGLAND; 1996 Nov;83(11):1522-5.

66. Ueda M, Takeuchi T, Takayasu T, Takahashi K, Okamoto S, Tanaka A, et al. Classification and surgical treatment of hepatocellular carcinoma (HCC) with bile duct thrombi. Hepatogastroenterology. GERMANY; 1994 Aug;41(4):349-54.

67. Shiomi M, Kamiya J, Nagino M, Uesaka K, Sano T, Hayakawa N, et al. Hepatocellular carcinoma with biliary tumor thrombi: aggressive operative approach after appropriate preoperative management. Surgery. United States; 2001 Jun;129(6):692-8.

68. Nakashima T, Okuda K, Kojiro M, Jimi A, Yamaguchi R, Sakamoto K, et al. Pathology of hepatocellular carcinoma in Japan. 232 Consecutive cases autopsied in ten years. Cancer. UNITED STATES; 1983 Mar;51(5):863-77.

69. Kojiro M, Kawabata K, Kawano Y, Shirai F, Takemoto N, Nakashima T. Hepatocellular carcinoma presenting as intrabile duct tumor growth: a clinicopathologic study of 24 cases. Cancer. UNITED STATES; 1982 May;49(10):2144-7.

70. Ikeda Y, Matsumata T, Adachi E, Hayashi H, Takenaka K, Sugimachi K. Hepatocellular carcinoma of the intrabiliary growth type. Int Surg. ITALY; 1997;82(1):76-8.

71. Mok KT, Chang HT, Liu SI, Jou NW, Tsai CC, Wang BW. Surgical treatment of hepatocellular carcinoma with biliary tumor thrombi. Int Surg. ITALY; 1996;81(3):284-8.

72. Wang HJ, Kim JH, Kim JH, Kim WH, Kim MW. Hepatocellular carcinoma with tumor thrombi in the bile duct. Hepatogastroenterology. GREECE; 1999;46(28):2495-9.

73. de'Angelis N, Landi F, Carra MC, Azoulay D. Managements of recurrent hepatocellular carcinoma after liver transplantation: A systematic review. World J Gastroenterol [Internet]. 2015 Oct 21 [cited 2017 Dec 2];21(39):11185. Available from: http://www.ncbi.nlm.nih.gov/ pubmed/26494973

74. Vitale A, Boccagni P, Kertusha X, Zanus G, D'Amico F, Lodo E, et al. Sorafenib for the Treatment of Recurrent Hepatocellular Carcinoma After Liver Transplantation? Transplant Proc [Internet]. 2012 Sep [cited 2017 Dec 2];44(7):1989-91. Available from: http://www.ncbi.nlm.nih.gov/ pubmed/22974889

75. Toso C, Cader S, Mentha-Dugerdil A, Meeberg G, Majno P, Morard I, et al. Factors predicting survival after post-transplant hepatocellular carcinoma recurrence. J Hepatobiliary Pancreat Sci [Internet]. 2013 Mar [cited 2017 Dec 2];20(3):342-7. Available from: http://www.ncbi. nlm.nih.gov/ pubmed/22710887

76. Taketomi A, Fukuhara T, Morita K, Kayashima H, Ninomiya M, Yamashita Y, et al. Improved Results of a Surgical Resection for the Recurrence of Hepatocellular Carcinoma After Living Donor Liver Transplantation. Ann Surg Oncol [Internet]. 2010 Sep 5 [cited 2017 Dec 2];17(9):2283-9. Available from: http://www.ncbi.nlm.nih.gov /pubmed/20204531

77. Shin WY, Suh K-S, Lee HW, Kim J, Kim T, Yi N-J, et al. Prognostic factors affecting survival after recurrence in adult living donor liver transplantation for hepatocellular carcinoma. Liver Transplant [Internet]. 2010 Feb 12 [cited 2017 Dec 2];16(5):678-84. Available from: http://www.ncbi.nlm.nih.gov/pubmed/20440777

78. Kornberg A, Küpper B, Tannapfel A, Katenkamp K, Thrum K, Habrecht 0 , et al. Long-term survival after recurrent hepatocellular carcinoma in liver transplant patients: Clinical patterns and outcome variables. Eur $\mathrm{J}$ Surg Oncol [Internet]. 2010 Mar [cited 2017 Dec 2];36(3):275-80. Available from: http://www.ncbi.nlm.nih.gov/pubmed/19857941

79. Toso C, Mentha G, Majno P. Liver Transplantation for Hepatocellular Carcinoma: Five Steps to Prevent Recurrence. Am J Transplant [Internet]. Blackwell Publishing Inc; 2011 Oct 1 [cited 2017 Dec 2];11(10):2031-5. Available from: http://doi.wiley.com/10.1111/j.1600-6143.2011.03689.x

80. Vivarelli M, Cucchetti A, Piscaglia F, La Barba G, Bolondi L, Cavallari A, et al. Analysis of risk factors for tumor recurrence after liver transplantation for hepatocellular carcinoma: Key role of immunosuppression. Liver Transplant [Internet]. 2005 May [cited 2017 Dec 2];11(5): 497-503. Available from: http://www.ncbi.nlm.nih.gov/pubmed/ 15838913

81. Hojo M, Morimoto T, Maluccio M, Asano T, Morimoto K, Lagman M, et al. Cyclosporine induces cancer progression by a cell-autonomous mechanism. Nature [Internet]. 1999 Feb 11 [cited 2017 Dec 2];397(6719):530-4. Available from: http://www.ncbi.nlm.nih.gov/ pubmed/10028970

82. Sapisochin G, Goldaracena N, Astete S, Laurence JM, Davidson D, Rafael E, et al. Benefit of Treating Hepatocellular Carcinoma Recurrence after Liver Transplantation and Analysis of Prognostic Factors for Survival in a Large Euro-American Series. Ann Surg Oncol [Internet]. 2015 Jul 4 [cited 2017 Dec 2];22(7):2286-94. Available from: http://www.ncbi.nlm.nih.gov/pubmed/25472651

83. Regalia E, Fassati LR, Valente U, Pulvirenti A, Damilano I, Dardano G, et al. Pattern and management of recurrent hepatocellular carcinoma after liver transplantation. J Hepatobiliary Pancreat Surg [Internet]. 1998 [cited 2017 Dec 2];5(1):29-34. Available from: http://www.ncbi.nlm.nih.gov/pubmed/9683751

84. Hwang S, Kim Y-H, Kim DK, Ahn C-S, Moon D-B, Kim K-H, et al. Resection of Pulmonary Metastases from Hepatocellular Carcinoma following Liver Transplantation. World J Surg [Internet]. 2012 Jul 13 [cited 2017 Dec 2];36(7):1592-602. Available from: http://www.ncbi. nlm.nih.gov/pubmed/22411088

85. Clavien P-A, Lesurtel M, Bossuyt PM, Gores GJ, Langer B, Perrier A, et al. Recommendations for liver transplantation for hepatocellular carcinoma: an international consensus conference report. Lancet Oncol [Internet]. 2012 Jan [cited 2017 Dec 2];13(1):e11-22. Available from: http://www.ncbi.nlm.nih.gov/pubmed/22047762

86. Rivera L, Giap H, Miller W, Fisher J, Hillebrand DJ, Marsh C, et al. Hepatic intra-arterial infusion of yttrium-90 microspheres in the treatment of recurrent hepatocellular carcinoma after liver transplantation: a case report. World J Gastroenterol [Internet]. 2006 Sep 21 [cited 2017 Dec 2];12(35):5729-32. Available from: http://www.ncbi.nlm. nih.gov/pubmed/17007031

87. Pfiffer TEF, Seehofer D, Nicolaou A, Neuhaus R, Riess H, Trappe RU. Recurrent hepatocellular carcinoma in liver transplant recipients: parameters affecting time to recurrence, treatment options and survival in the sorafenib era. Tumori [Internet]. 2011 [cited 2017 Dec 2];97(4):436-41. Available from: http://www.ncbi.nlm.nih.gov /pubmed/21989430

88. Ko HK, Ko G-Y, Yoon HK, Sung K-B. Tumor response to transcatheter arterial chemoembolization in recurrent hepatocellular carcinoma after living donor liver transplantation. Korean J Radiol [Internet]. 2007 [cited 2017 Dec 2];8(4):320-7. Available from: https://synapse.koreamed.org/DOlx.php?id=10.3348/kj.2007.8.4.320 